\title{
ANALISIS PENGUKURAN KINERJA PERUSAHAAN DAERAH AIR MINUM KABUPATEN BULELENG DENGAN PENDEKATAN BALANCED SCORECARD
}

\author{
Ni Kadek Yeni Purnami, Ni Luh Nonik Pratiwi, \\ Ni Kadek Mey Sariliani, Nuridin, Rizki Firdi Sjahril \\ Jurusan Akuntansi, Universitas Pendidikan Ganesha, Singaraja, Bali, Indonesia
}

\begin{abstract}
Abstrak
Penelitian ini bertujuan untuk menganalisa pengukuran kinerja PDAM Kabupaten Buleleng dengan pendekatan Balanced Scorecard. Dari hasil penelitan pengelolaan keuangan, operasional dan administrasi pada PDAM di Kabupaten Buleleng di atur secara baik dan sudah sesuai dengan BPKP ( Badan Pengawas Keuangan dan Pembangunan). dengan menggunakan standar yang telah diterapkan yaitu BPKP sangat minim Kendala pembuatan laporan internal dan eksternal . tingkat keberhasilan kinerja tahun 2015 menggunakan ukuran kinerja ROI dan Profit Margin sehingga hasilnya pengukuran perspektif keuangan PDAM Kabupaten Buleleng tahun 2014 dan tahunjh 2015 yaitu dilihat ukuran kinerja ROI dari tahun 2014-2015 mengalami peningkatan sebesar 4,98\%. Hal ini berarti bahwa tingkat pengembalian atas investasi / Return on Investment (ROI) yang dilakukan mengalami peningkatan laba yang baik yaitu sebesar $4,98 \%$. Sedangkan dengan Profit Margin bahwa nilai Profit Margin yang diperoleh perusahaan pada tahun 2014-2015 mengalami peningkatan sebesar $4,38 \%$. Hal ini menunjukkan bahwa kinerja perusahaan dalam memperoleh laba mengalami peningkatan.
\end{abstract}

Kata kunci: Balanced Scorecard,Kinerja, PDAM.

\section{Abstract}

This study aims to analyze the performance measurement of PDAM Buleleng Regency with the Balanced Scorecard approach. From the results of research on financial management, operations and administration of PDAMs in Buleleng Regency, they are well managed and in accordance with the BPKP (Financial and Development Supervisory Agency). by using the standards that have been applied namely BPKP is very minimal Constraints for making internal and external reports. the success rate of performance in 2015 uses ROI and Profit Margin performance measures so that the results of the measurement of the financial perspective of PDAM Buleleng Regency in 2014 and 2015 which is seen from the ROI performance measurement from 2014-2015 increased by $4.98 \%$. This means that the rate of return on investment (Return on Investment (ROI) has experienced an increase in good profit that is equal to $4.98 \%$. Whereas with Profit Margin that the value of Profit Margin obtained by the company in 2014-2015 increased by 4.38\%. This shows that the company's performance in obtaining profits has increased.

Keywords : Balanced Scorecard, Performance, PDAM.

\section{Pendahuluan}

Pengukuran kinerja pada dasarnya merupakan proses menganalisa tingkat keberhasilan suatu kelompok kerja, program atau usaha-usaha organisasi dengan membandingkan data actual dan perencanaan. Pengukuran kinerja juga dapat diartikan sebagai pemilihan dan penggunanan ukuran-ukuran kuantitatif terkait kapasitas, prosesproses dan hasil-hasil dalam rangka membangun informasi mengenai aspek-aspek kritis atas aktivitas, termasuk pengaruhnya terhadap masyarakat. Penggukuran organisasi pemerintahan sejatinya merupakan suatu hal yang begitu kompleks dan senantiasa menjadi perdebatan hangat. Pengukuran kinerja merupakan salah satu bagian dari Sistem Akuntabilitas Kinerja Instansi Pemerintahan (SAKIP). SAKIP sendiri merupakan sebuah rangkaian sistematik dari berbagai aktivitas, alat, dan prosedur yang dirancang untuk penetapan dan pengukuran,pengumpulan data, pengklasifikasian, pengikhtisaran ,dan 
pelaporan kinerja pada instansi pemerintah, dalam rangka peretanggung jawaban dan peningkatan kinerja instansi pemerintahan. Secara umum, pengukuran kinerja dilakukan dengan membandingkan antara kinerja yang seharusnya terjadi dengan kinerja yang diharapkan baik secara berkala maupun tahunan. Pengukuran kinerja dilakukan dalam rangka menjamin adanya peningkatan dalam pelayanan public dan menungkatkan akuntabilitas dengan melakukan klarifikasi output dan outcome yang akan dan seharusnya dicapai untuk memudahkan terwujudnya organisasi yang akuntabel. Pengukuran kinerja merupakan hal terpentimg bagi suatu organisasi baik pemerintah maupun suasta sebagai dasar atau acuan dalam meningkatkan layanan yang diberikan oleh sebab ini maka kami mengangkat tema " Pengukuran Kinerja Pada Organisasi Pemrintahan" dengan menggunakan sarana observasi untuk memperoleh sebuah data yang aktual yaitu Perusahaan Daerah Air Minum (PDAM) Kabupaten Buleleng Tingkat II Buleleng. Perusahaan Daerah Air Minum (PDAM) merupakan suatu unit usaha milik daerah yang bergerak dalam distribusi air bersih bagi masyarakat umum, Perusahaan Daerah Air Minum adalah suatu perusahaan daerah sebagai sarana penyedia air bersih yang diawasi dan dimonitor oleh aparat-aparat eksekutif maupun legislative daerah. Masyarakat pada dasarnya sangat tergantung terhadap Perusahaan Daerah Air Minum sebab segala kebutuhan rumah tangga maupun unit usaha sangat memerlukan air bersih sebagai penunjang kehidupannya. Banyak masyarakat di daerah buleleng yang menerima jasa pelayanan dari Perusahaan Daerah Air Minum. Dalam hal ini kita tidak hanya melihat dari segi pemberian jasa atau layanan terhatap public saja tetapi ada aspek lain yang harus diukur dalam Perusahaan Daerah Air Minum. Untuk mengukur kinerja dari PDAM KAbupaten Buleleng penulis menggunakan pendekatan dengan metode Balanced Scorecard. Balance Scorecard (BSC) adalah suatu pendekatan untuk mengukur kinerja perusahaan yang di tinjau dari perspektif financial (financial perspective) dan perspektif non financial (customer perspective, internal business process perspective, dan learning and growth perspective) secara seimbang. Balance Scorecard terdiri dari dua kata yaitu balance dan scorecard. Scorecard artinya kartu skor, maksudnya adalah kartu score yang digunakan untuk merencanakan skor yang diwujudkan di masa yang akan datang, sedangkan balanced artinya berimbang, maksudnya dalah untuk mengukur kinerja seseorang diukur secara berimbang dari dua perspektif yaitu keuanagn dan non keuangan, jangka pendek dan jangka panjang, intern dan ekstern. (Zudia, 2010)

Dari-faktor-faktor inilah yang melatar belakangi peneliti tetarik untuk meneliti perusahaan ini dengan judul "ANALISIS PENGUKURAN KINERJA PERUSAHAAN DAERAH AIR MINUM KABUPATEN BULELENG DENGAN PENDEKATAN BALANCED SCORECARD “.

Berdasarkan latar belakang diatas, masalah yang dapat dirumuskan adalah bagaimana analisa pengukuran kinerja PDAM Kabupaten Buleleng dengan pendekatan Balanced Scorecard.

\section{Pembahasan}

\section{Perspektif Keuangan (Financial Perspektive)}

Perspektif keuangan tetap menjadi perhatian dalam balanced scorecard, karena ukuran keuangan merupakan ikhtisar dari konsekuensi ekonomi yang terjadi yang disebabkan oleh pengambilan keputusan Perspektif keuangan menunjukkan perencanaan, implementasi dan pelaksanaan dari strategi perusahaan dapat memberikan perbaikan yang pengukuran keseluruhan melalu presentase rata-rata pertumbuhan pendapatan, dan ratarata pertumbuhan penjualan dalam taerget market. (Aurora, 2010)

Pengukuran kinerja keuangan mempertimbangkan adanya tahapan dari siklus kehidupan bisnis, yaitu:

1. Growth (bertumbuh). Merupakan tahap awal dari siklus sutau bisnis, pada tahap ini akan diharapkan suatu bisnis memiliki produk baru yang di rasa sangat potensial bagi bisnis tersebut. Untuk itu, maka pada tahap growth perlu dipertimbangkan mengenai sumber daya untuk mengembangkan produk baru dan meningkatkan layanan, membangun serta mengembangkan fasilitas yang menjunjang produksi, investasi pada 
sistem, infrastruktur dan jaringan distribusi yang akan mendukung terbentuknya hubungan kerja secara menyeluruh dalm mengembangkan hubungan baik dengan pelanggan. Secara keseluruhan tujuan financial pada tahap ini adalah mengukur persentase tingkat pertumbuhan pendapatan, dan tingkat pertumbuhan penjualan dipasar sasaran.

2. Sustain (bertahap). Pada tahap ini timbul pertanyaan mengenai akan ditariknya investasi atau melakukan investasi kembali dengan mempertimbangkan tingkat pengembalian yang mereka investasikan. Pada tahap ini tujuan financial yang hendak dicapai adalah untuk memperoleh keuntungan.

3. Harvest (menuai). Tahap ketiag dimana suatu organisasi atau badanusaha akan berusaha untuk mempertahankan bisnisnya. Tujuan financial dari tahap ini adalah untuk meningkatkan aliran kas dan mengurangi aliran dana.

\section{Perspektif Pelanggan (CustomerPerspektive)}

Dalm perspektif pelanggan, perusahan harus terlebih dahulu menentukan segmen pasar dan pelangganyang menjadi target bagi organisasi atau badan usaha. Selanjutnya, manajer harus menentukan alat ukur yang terbaik untuk mengukur kinerja dari tiap unit operasi dalam upaya mencapai target finansialnya. Selanjutnya, apabila suatu unit bisnis ingin mencapai kinerja keuangan ynag superior dalam jangka panajang maka harus menciptakan dan menyajika suatu produk baru/jasa yang bernilai lebih baik kepada pelanggan mereka. (Kaplan dan Norton, 1996).

Perspektif pelanggan memiliki dua kelompok pengukuran, yaitu:

1. Kelompok Pengukuran Pelanggan Utama (Core Measurement Group). Kelompok pengukuran ini digunakan untuk mengukur bagaimana perusahaan memenuhi kebutuhan pelanggan dalam mencapai kepuasan, mempertahankan, memperoleh, dna merebut pangsa pasar yang telah ditargekan. Dalam kelompok pengukuran ini mempunyai lima tolak ukur anatara lain:

a. Pangsa pasar (Market share), mengukur seberapa besar proporsi segmen pasar tertentu yang dikuasai oleh perusahaan.

b. Tingkat perolehan pelanggan (Customer acquisition), mengukur seberapa banyak perusahaan berhasil menarik pelanggan-pelanggan baru.

c. Kemampuan mempertahankan para pelnaggan lama (Customer retention), mengukur seberapa banyak perusahaan berhasil mempertahankan pelangganpelanggan lama.

d. Tingkat kepuasan pelanggan (Customer satisfaction), mengukur seberapa jauh para pelanggan merasa puas terhadap layanan perusahaan.

e. Tingkat profitabilitas pelanggan (Customer profitability), mengukur seberapa besar keuntungan yang berhasil diraih oleh perusahaan dari penjualan produk kepada para pelanggan.

2. Kelompok Pengukur Nilai Pelanggan (Customer Value Proposition). Digunakan untuk mengetahui bagaimana perusahaan mengukur nilai pasar yang mereka kuasai dan mengukur pasar yang potensial yang mungkin bias mereka masuki. Kelompok pengukuran ini juga dapat menggambarkan pemacu kinerja yang menyangkut apa yang harus disajikan perusahaan untuk mencapai tingkat kepuasan, loyalitas, retensi, dan akuisisi pelanggan yang tinggi. Value proposition menggambarkan atribut yang disajikan perusahaan dalam produk/jasa yang dijual untuk meniptakan loyalitas dan kepuasan pelangga. Kelompok pengukuran nilai pelanggan terdiri dari:

a. Atribut produk/jasa, yang meliputi: fungsi, harga dan kulitas produk.

b. Hubungan dengan pelanggan yang meliputi: distribusi produk keplakda pelanggan, termmask respn dari perusahaan, waktu pengiriman, dan bagaimana perasaan pelanggan setelah membeli produk/jasa dari perusahaan yang bersangkutan.

c. Citra atau reputasi, yang menggambarkan factor-faktor yang tak berwujud bagi perusahaan utuk menarimpelanggan untuk berhubungan dengan perusahaan, atau membeli produk. 


\section{Perspektif Proses Bisnis Internal (Internal Business Process Perspektive)}

Perspektif proses bisnis internal menampilkan proses kritis yang memungkinkan unit bisnis untuk meberi value proposition yang mampu menarik dan mempertahankan pelanggannya di segmen pasar yang diingkinkan dan memuaskan harapan para pelanggan saham melalui financial returns. Tiap-tiap perusahaan mempunyai seperangkat proses penciptaan nilai yang unik bagi pelanggannya. Secara umum, Kaplan dan Norton (1996) membagi dalam tiga prinsip dasar yaitu:

1. Proses inovasi, adalh bagian terpenting dalam keseluruhan prose sproduksi. Tetapi ada juga perusahaan yang menempatkan iovasi diluar proses produksi. Didalam proses invasi itu sendiri terdiri atas dua komponene yaitu identifikasi keinginan pelaggan dan melakukan perancangan produk yangs esuai dengan keinginan pelanggan. Bila hasil inovasi dari pelanggan tidak sesuai dengan keinginanan pelanggan, amka produk tidak akan mencapat tanggapan positif dari pelanggan, sehingga tidak memberi tambahan pendapatan agi perusahaan bahkan perusahaan harus megeluarkan biaya investasi pada proses penelitian dan pengemangan.

2. Proses Operasi, adalah aktivitas yang dilakukan perusahaan mulai dari saat penerimaan order dari pelanggan sampai produk dikirim ke pelanggan. Proses operasi menekankan pada penyamapian produk kepada pelanggan secara efisien, dan tepat waktu. Proses ini berdasarkan fakta menjadi focus utama dari sistem pengukuran kinerja sebagian besar organisasi.

3. Pelayanan Purna Jual, yang diaksud disini dapat berupa garansi, penggantian untuk produk yang rusak, dll.

\section{Perspektif Pembelajaran dan Pertubuhan (Learning and Growth Perspective)}

Kaplan (Kaplan dan Norton, 1996) mengungkapkan betapa pentingnya suatu organisasi bsisnis untuk terus mempertahankan karyawannya, memantau kesejahteraan karyawan dan meningkatkan oengetahuan karyawan karena dapat meningkatkan tingkat pengetahuan akan meningkat pula kemampuan karyawan untuk berpartisipasi dalam penncapaian hasil ketiga perspektif di atas dan tujuan perusahaan. Perspektif pembelajaran dan pertumbuhan organisasi merupakan factor pendorong dihasilkannya kinerja ynag istimewa dalam tiga perspektif balanced scorecard.

Perspektif pembelanjaan dan pertumbuhan mencangkup tiga prinsip kapabilitas yang terkait dengan kondisi internal perusahaan, yaitu:

1. Kapabilitas Pekerja, merupakan bagian kontribusi pekerja dan perusahaan. Sehubugan dnegan kapabilitas pekerja, ada tiga hal yang harus diperhatikan oleh manajemen:

a. Kepuasan pekerja, merupakan prokondisi untuk meningkatkan produktivitas, tanggungjawab, kualitas, dan pelayanan pada konsumen. Unsure yang dapat diukur dalam kepuasan pekerja adalah keterlibatan pekerja dalam mengambil keputusan, pengakuan, akses untuk mendapat informasi, doronganuntuk berkerja kreatif, dan menggunakan inisiatif, serta dukungan dari atasan.

b. Retensi pekerja, adalah kemapauan untuk memepertahankan pekerja yang terbaik dalam perusahaan. Dimana kita mengetahui pekerja merupakan investasi jangaka panajang bagi perusahaan. Jadi, keluarnya seorang pekerja yang bukan karena keinginan perusahaan merupakan loss pada intellectual capital dari perusahaan. Retensi pekerja diukur dnegan persentase turnover di perusahaan.

c. Produktivitas pekerja, merupakan hasil dari pengaruh keseluruhandari peningkatan keahlian dan moral, inovasi, proses internal, dan kepuasan pelanggan. Tujuannya adalah untuk menghubungan outputyang dihasilkan oleh pekerja dnegan jumlah pekerja yang seluruhnya untuk meghasilkan outpur tersebut.

2. Kapabilitas Sistem Informasi, adapaun yang menjadi tolak ukur kapasitas sistem informasi adlaah tigkat keersediaan informasi, tingkat ketepatan informasi yang tersedia, serta jangka waktu untuk memperoleh informasi yang dibutuhkan.

3. Iklim organisasi yang mendorong timbulnya motivasi, dan pemberdayaan adalah pening untuk menciptakan pekerja yang berinisiatif. Adapun yang menjadi tolak ukur hal tersebut adalah jumlah saran yang diberikan pekerja. 


\section{Keunggulan Balanced Scorecard}

Keunggulan konsep balanced scorecard (BSC) dalam sistem perencanaan strategik adalah mampu menghasilakn rencana yang strategic yang memeiliki karakteristik sebagai berikut (Aurora, 2010):

1. Komprehensif. (BSC) memperluas perspektif yang dicakup dalam perencanaan startegik. Perluasaan perspektif rencana strategik ke perspektif non keuangan tersebut menghasilkan manfaat yang terdiri dari: menjanjikan kinerja keuangan yang berlipat ganda dan berkesinambungan, kemampuan organisasi untu memasuki lingkungan bisnis yang kompleks.

2. Koheren. BSC mewajibkan personel untuk membangun hubungan sebab akibat diantara berbagai sasaran strategik yang dihasilkan dalam perencanaan strategic.

3. Berimbang. Keseimbangan sasaran strategic yang dihasilkan oleh sistem perencanaan strategic penting untuk menghasilkan kinerja keuangan berjangka panjang.

4. Terukur. Keterukuran sasaran strategik yang dihasilkan oleh sistem perencanaan strategic menjanjikan keteercapaian berbagai sasaran strategik yang dihasilkan oleh sistem tersebut

Dalam

mengukur kinerja PDAM Kabupaten Buleleng penulis menggunakan 2 aspek pengukuran yaitu mengukur kinerja perspektif keuangan dan perspektif pelanggan.

\section{Mengukur Kinerja Perspektif Keuangan.}

Dalam mengukur perspektif keuangan ini digunakan perhitungan terhadap :

Tabel 1 Hasil Pengukuran Perspektif Keuangan PDAM Kabupaten Buleleng Tahun 2014 dan Tahun 2015.

\begin{tabular}{|l|l|l|}
\hline Ukuran KInerja & Hasil Tahun 2014 & Hasil Tahun 2015 \\
\hline ROI & $13,89 \%$ & $18,87 \%$ \\
\hline Profit Margin & $14,21 \%$ & $18,59 \%$ \\
\hline
\end{tabular}

Sumber : Data Diolah.

a. Return on Investment (ROI).

Indikator ROI bertujuan untuk mengukur peningkatan laba bersih yang dihasilkan dari PDAM Kabupaten Buleleng pada Tahun 2014-2015 yang diukur dengan membagi prosentase laba bersih dengan total aktiva.

$\mathrm{ROI}=\frac{\text { Laba Bersih }}{\text { Total Aktiva }} \times 100 \%$

1. Tahun 2014

$$
\begin{aligned}
\mathrm{ROI} & =\frac{4.970 .005 .939,27}{35.791 .281 .955,87} \times 100 \% \\
\mathrm{ROI} & =13,89 \%
\end{aligned}
$$

2. Tahun 2015

$\mathrm{ROI}=\frac{8.326 .511 .540,79}{44.126 .632 .524,97} \times 100 \%$

$\mathrm{ROI}=18,87 \%$

Dari table tersebut dapat dilihat bahwa ROI dari tahun 2014-2015mengalami peningkatan sebesar 4,98\% (18,87\% - 13,89\%=4,98\%). Hal ini berarti bahwa tingkat pengembalian atas investasi /Return on Investement (ROI) yang dilakukan mengalami peningkatan laba yang baik yaitu sebesar $4,98 \%$.

b. Profit Margin.

Profit margin merupakan salah satu rasiorentabilitas yang menggambarkan laba rugi bersih per penjualan yang dihasilkan. Apabila profit Margin sesuai atau melebihi targer yang telah ditetapkan sebelumnya, berarti target perusahaan telah terpenuhi dan menunjukkan semakin baiknya kinerja perusahaan dalam memperoleh laba. Profit margin dapat diukur dengan membandingkan laba bersih dengan penjualan.

Profit Margin $=\frac{\text { Laba Bersih }}{\text { Penjualan }} \times 100 \%$

- Tahun 2014 


\section{Perspektif Pelanggan.}

Profit Margin $=\frac{4.970 .005 .939,27}{34.965 .939 .064,00} \times 100 \%$

Profit Margin $=14,21 \%$

- Tahun 2015

Profit Margin $=\frac{8.326 .511 .540,79}{44.786 .558 .228,00} \times 100 \%$

Profit Margin = 18,59\%

Dari table tersebut dapat dilihat bahwa nilai Profit Margin yang di peroleh perusahaan pada tahun 2014-2015 mengalami peningkatan sebesar $4,38 \%(18,59 \%-14,21 \%=4,38 \%)$. Hal ini memnunjukkan bahwa kinerja perusahaan dalam memperoleh laba mengalami peningkatan.

Perspektif yang paling menjadi perhatian dalam pengukuran kinerja menggunakan metode balanced scorecard adalah kinerja yang berkaitan dengan bagaimana menciptakan persepsi yang baik dari pelanggan. Tujuan dari perspektif ini adalah untuk meningkatkan kepercayaan dan kepuasan pelanggan terhadap perusahaan.

a. Custumer Retention

Perusahaan dapat menggunakan ukuran customer retention untuk mengukur tingkat sejauh mana perusahaan dapat mempertahankan hubungan dengan pelanggan. Apabila customer retention menunjukkan nilai $100 \%$ berarti perusahaan dapat mempertahankan semua pelanggan lama. Berikut ini adalah hasil perhitungan customer retention PDAM Kabupaten Buleleng periode 2014-2015 adalah sebagai berikut.

Table 2. Customer Retention pada PDAM Kabupaten Buleleng

\begin{tabular}{|l|l|l|}
\hline Keterangan & 2014 & 2015 \\
\hline Total pelanggan & 265.916 & 282.852 \\
\hline $\begin{array}{l}\text { Jumlah Pelanggan } \\
\text { Tetap }\end{array}$ & 41.515 & 44.369 \\
\hline Customer Retention & $15,61 \%$ & $15,68 \%$ \\
\hline
\end{tabular}

a. Tahun 2014

$$
\begin{aligned}
\text { Customer Retention }= & \frac{\text { Jumlah } \text { Pelanggan } \text { Tetap }}{\text { Total Pelanggan }} \times 100 \% \\
& =\frac{41.515}{265.916} \times 100 \%=15,61 \%
\end{aligned}
$$

b. Tahun 2015

$$
\begin{aligned}
\text { Customer Retention }= & \frac{\text { Jumlah } \text { Pelanggan } \text { Tetap }}{\text { Total Pelanggan }} X 100 \% \\
& =\frac{44.369}{282.852} \times 100 \%=15,68 \%
\end{aligned}
$$

Dari table tersebut menunjukkan bahwa kinerja PDAM Kabupaten Buleleng pada tahun 2015 mengalami peningkatan sebesar $0.07 \%$ hal ini menunjukkan bahwa dalam mempertahankan pelanggannya cukup baik terbukti dari kenaikan jumlah pelanggan dan pingkatan jumlah pelanggan yang bertahan pada tahun 2015.

b. Customer Acquistion

Customer Acquistion dalam perspektif pelanggan digunakan untuk mengukur tingkat kemampuan perusahaan dalam memperoleh tambahan pelanggan baru, selain pelanggan lama. Hal ini dapat dilihat dari persentase tambaahn pelanggan baru yang telah berhasil diperoleh PDAM Kabupaten Buleleng.

Tabel 3. Customer Acquistion PDAM Kabupaten Buleleng

\begin{tabular}{|l|l|l|}
\hline Keterangan & 2014 & 2015 \\
\hline Pelanggan baru & 1.228 & 2.854 \\
\hline
\end{tabular}




\begin{tabular}{|l|l|l|}
\hline Jumlah Pelanggan & 41.515 & 44.369 \\
\hline Customer Acquistion & $2.96 \%$ & $6.43 \%$ \\
\hline
\end{tabular}

a. Tahun 2014

$$
\begin{aligned}
\text { Customor Acquistion }= & \frac{\text { Jumlah Pelanggan Baru }}{\text { Total Pelanggan }} X 100 \% \\
& =\frac{1.228}{41.515} \times 100 \%=2.96 \%
\end{aligned}
$$

b. Tahun 2015

$$
\begin{aligned}
\text { Customor Acquistion }= & \frac{\text { Jumlah } \text { Pelanggan Baru }}{\text { Total Pelanggan }} X 100 \% \\
& =\frac{2.854}{44.369} \times 100 \%=6.43 \%
\end{aligned}
$$

Dari table diatas menunjukkan bahwa Customor Acquistion PDAM Kabupaten Buleleng mengalami peningkatan setiap tahunnya. Hal ini menunjukkan bahwa kinerja PDAM Kabupaten Buleleng berhasil menarik pelanggan baru.

c. Tingkat Kepuasan Pelanggan.

Tingkat kepuasaan konsumen digunakan untuk mengetahui sejauh mana derajat kualitas pelayanan langsung PDAM Kabupaten Buleleng kepada konsumen. Hal ini dilakukan dengan melakukan wawancara langsung kepada masyarakat sekitar yang menjadi pelanggan PDAM Kabupaten Buleleng. Dari hasil wawancara yang kami lakukan terhadap masyarakat sekitar dapat kami simpulkan bahwa pelayanan PDAM Kabupaten Buleleng dan kepuasaan pelanggan terhadap pelayanan yang diberikan cukup baik ini terbukti dengan adanya pengecekan secara berkala atau pergantian terhadap water meter pelanggan yang sudah tidak layah. Selain itu pelayanan terhadap penyambungan baru juga sudah terealisasi dengan baik karena pelayanan penyambungan baru cepat dapat diselesaikan. Bukan hanya hal itu saja tetapi penanganan terhadap pengaduan cepat teratasi sebab saat pengaduan itu di ajukan maka segera petugas yang bersangkutan langsung datang untuk menangani permasalahan.

\section{Mengukur Kinerja Perspektif Proses Bisnis Internal.}

a. Inovasi

Pada PDAM Kabupaten Buleleng dapat dilihat inovasi yang telah dilakukan oleh perusahaan, yaitu adanya kemudahan pelayanan yang diberikan ini disebabkan oleh tersedianya service point diluar Kantor Pusat. Inovasi lainnya yaitu PDAM Kabupaten Buleleng telah melakukan pengawasan internal atas kualitas air minum sesuai dengan Permenkes No.736/MENKES/PER/VI/2010 tentang Tata Laksana Pengawasan Kualitas Air Minum. Inovasi selanjutnya yaitu meningkatkan utilitas kapasitas riil dengan meningkatkan jam operasional produksi, penambahan daya dan menambah reservoir.

\section{b. Layanan Purna Jual.}

Dalam layanan purna jual ini perusahaan memberikan beberapa pelayanan prima antara lain telah dilaksanakannya pelayanan On Line Sistem mulai dari pendaftaran, perhitungan rekening, tunggakan rekening, pembayaran rekening. Selain itu dapat juga mengakses web PDAM Kabupaten Buleleng dan pelayanan melalui call center untuk informasi jumalah tagihan pelanggan, satuan reaksi cepat dalam penanggulangan kebocoran dan pengaduan masyarakat. Hal ini bertujuan untuk memberikan pelayanan kepada pelanggan dengan harapan mendapat rasa puas dari mereka.

\section{Mengukur Kinerja Perspektif Pembelajaran dan Pertumbuhan.}

Pada pengukuran kinerja perspektif pembelajaran dan pertumbuhan penulis menilai bahwa pada pengukuran ini PDAM Kabupaten Buleleng dinilai baik karena untuk mampu mempertahankan susunan dewan direksi dan dewan pengawas dari tahun 2013 hingga saat ini. Selain itu PDAM kabupaten buleleng juga mampu mempertahankan 
jumlah pegawai yaitu sebanyah 224 orang pegawai yang terdiri dari 198 pegawai tetap dan 26 orang pegawai honorer di mana ke 224 orang pegawai ini telah mengikuti diklat pegawai atau peningkatan kompentensi guna meningkatkan pengetahuan yang akan meningkatkan pula kemampuan karyawan untuk berpatisipasi dalam pencapaian hasil ketiga perspektif di atas dan tujuan perusahaan.

\section{Simpulan dan Saran}

Berdasarkan pemaparan diatas, simpulan yang didapat adalah pengelolaan keuangan, operasional dan administrasi pada PDAM di Kabupaten Buleleng di atur secara baik dan sudah sesuai dengan BPKP ( Badan Pengawas Keuangan dan Pembangunan ). dengan menggunakan standar yang telah diterapkan yaitu BPKP sangat minim Kendala pembuatan laporan internal dan eksternal . tingkat keberhasilan kinerja tahun 2015 menggunakan ukuran kinerja ROI dan Profit Margin sehingga hasilnya pengukuran perspektif keuangan PDAM Kabupaten Buleleng tahun 2014 dan tahunjh 2015 yaitu dilihat ukuran kinerja ROI dari tahun 2014-2015 mengalami peningkatan sebesar 4,98\%. Hal ini berarti bahwa tingkat pengembalian atas investasi / Return on Investment (ROI) yang dilakukan mengalami peningkatan laba yang baik yaitu sebesar 4,98\%. Sedangkan dengan Profit Margin bahwa nilai Profit Margin yang diperoleh perusahaan pada tahun 2014-2015 mengalami peningkatan sebesar $4,38 \%$. Hal ini menunjukkan bahwa kinerja perusahaan dalam memperoleh laba mengalami peningkatan. Kinerja PDAM Kabupaten Buleleng pada tahun 2015 mengalami peningkatan sebesar $0.07 \%$ dalam mempertahankan hubungan dengan pelanggan lama, hal ini menunjukkan bahwa dalam mempertahankan pelanggannya cukup baik terbukti dari kenaikan jumlah pelanggan dan peningkatan jumlah pelanggan yang bertahan. Customor Acquistion PDAM Kabupaten Buleleng mengalami peningkatan setiap tahunnya. Hal ini menunjukkan bahwa kinerja PDAM Kabupaten Buleleng berhasil menarik pelanggan baru. Dalam pengukuran kinerja terhadap tinmgkat kepuasaan pelanggan PDAM kabupaten Buleleng dalam kinerjanya di anggap sudah baik karena adanya peningkatan pelayanan yang diberikan. Pada pengukuran kinerja perspektif pembelajaran dan pertumbuhan penulis menilai bahwa pada pengukuran ini PDAM Kabupaten Buleleng dinilai baik karena untuk mampu mempertahankan susunan dewan direksi dan dewan pengawas dari tahun 2013 hingga saat ini. Selain itu PDAM kabupaten buleleng juga mampu mempertahankan jumlah pegawainya.

Disamping itu, saran yang dapat diberikan adalah penulis bisa meningkatkan kreatifitas dan ilmunya sehingga dapat membuat makalah yang dapat dibaca oleh orang banyak dan tentunya berguna bagi kehidupan sehari-hari, pembaca harus memahami betul agar nantinya dapat diaplikasikan ke dalam kehidupan nyata, pemerintah dapat meningkatkan kinerjanya dan lebih memahami kondisi yang ada sehingga makalah ini dapat membantu kinerja pemerintah dalam mengatasi beragam permasalahan yang sedang terjadi, serta perusahaan dapat meningkatkan kembali kinerjanya agar nantinya dapat memeberikan pelayann yang lebih op[timal terhadap masyarakat dan sekitarnya.

\section{DAFTAR PUSTAKA}

Prayudi aristia, Kurniawan Adi.2016.Akuntansi Pemerintahan.Singaraja: Istiqlal Publishing Group

http://www.google.co.id/search?hl=id\&ie=ISO-8859-1\&q=penerapan+balanced+scorecard+sebagai+tolak+ukur+penilaian+kinerja+pada+perusahaan+daer $\underline{\text { ah+air+minum }}$ 